\title{
Genealogía de un origen: Túbal, el falsario y la Atlántida en la Historia de los Incas de Pedro Sarmiento de Gamboa ${ }^{1}$
}

por

Soledad González Díaz

CONICYT

El presente artículo propone una lectura política de dos libros vinculados entre sí: la Historia de los Incas de Pedro Sarmiento de Gamboa y la Antiquitatum Variarum de Annio de Viterbo, una colección de textos espurios de fines del siglo XV. Haciendo una sintesis entre la Antiquitatum y el mito platónico de la Atlántida, Sarmiento argumentó que los indios descendian de la estirpe de Túbal, el nieto de Noé y fundador de la monarquía hispánica, que habia llegado a las Indias después del Diluvio Universal. Se propone que tanto la Historia de los Incas como la Antiquitatum formaron parte de una corriente oficial de representación del pasado de corte imperial promovida por los Reyes Católicos, que se proyectó a las crónicas hispanas y a las de Indias en el transcurso del siglo XVI.

Palabras Clave: Sarmiento de Gamboa; Annio de Viterbo; Túbal; Atlántida; poblamiento de las Indias occidentales.

${ }^{1}$ El presente artículo se realizó en el contexto del proyecto de investigación FONDECYT 1100132 «Historia de los Pueblos Andinos de Arica, Tarapacá y Atacama: las Políticas Estatales y Eclesiásticas y las Dinámicas de las Poblaciones Indígenas, Siglos XVI-XVIII», cuyo investigador responsable es el Dr. Jorge Hidalgo Lehuedé de la Universidad de Chile. La autora agradece los oportunos comentarios de los evaluadores de este artículo.

2 Tesista del Programa de Doctorado en Filología Española de la Universidad Autónoma de Barcelona y Becaria del Programa de Capital Humano Avanzado CONICYT, Chile. 
La Historia de LOS INCAS COMO UNA CRÓNICA POLÍTICA

Pedro Sarmiento de Gamboa es recordado no solo por su labor como cronista del Perú, sino también por las múltiples facetas que su agitada vida tuvo. Con alrededor de 23 años arribó a Nueva España y luego se dirigió al virreinato del Perú, en donde se convirtió en un estrecho colaborador del virrey Toledo al formar parte de la comitiva que este nombró para que lo acompañase en su célebre revisita de 1570, cuyo objetivo fue recopilar información sobre lo que había sido la administración incaica en las localidades de Huarochirí, Jauja, Huamanga y el Cuzco. Sarmiento utilizó gran parte de estas averiguaciones en la redacción de la Historia de los Incas, concebida inicialmente como la segunda parte de un proyecto de mayor envergadura del cual solo se conoce esta crónica. Fuera de su labor como cronista, Sarmiento también es recordado por los varios viajes que emprendió como navegante, entre los cuales destacan haber formado parte de la expedición que a cargo de Álvaro de Mendaña descubrió las islas Salomón y, posteriormente, el intento fallido de colonización del Estrecho de Magallanes ${ }^{3}$.

La Historia de los Incas narra en setenta y un capítulos la historia del linaje real de los Incas desde sus orígenes hasta Huáscar y Atahualpa, dentro de los cuales los cinco primeros capítulos tratan del origen de los habitantes de las Indias, pobladas después del Diluvio Universal. A través de toda la crónica, Sarmiento insiste en que los Incas no habían sido señores naturales de los Andes y que, por ende, su gobierno había sido ilegítimo y constituía una tiranía. Más aún, no solo habían sido tiranos contra los naturales del Perú sino también contra ellos mismos, puesto que tampoco habían respetado el derecho de primogenitura que tenían ordenado mantener por sus propias le$y^{4}{ }^{4}$. En consecuencia, la suya es una historia en la que abundan las guerras y las intrigas entre hermanos y parientes por la sucesión al trono, que evidencia a cada momento la crueldad con que los Incas iban sumando territorios a su Imperio en constante expansión. Esta visión del Incario justificó el proyecto político y administrativo del virrey Toledo, puesto que aceptar el señorío

3 Cf. Barros, 2002.

4 «más aún, - lo ques sobre todo de notar, para acabar de entender las pésimas inclinaciones destos tiranos y su horrenda avaricia y tiranía - no se contentaron con ser malos tiranos para los dichos naturales, pero contra sus propios hijos, hermanos, parientes y sangre propia, y contra sus propias leyes y estatutos se precieron de ser y fueron pésimos y pertinacísimos foedífragos tiranos con un género de inhumanidad inaudita». Sarmiento de Gamboa, 1942: 185. Foedifrago (Lt): que viola los tratados. 
natural de los Incas implicaba, siguiendo a Francisco de Vitoria, la pérdida del dominio hispano en los territorios recientemente conquistados ${ }^{5}$.

Una vez terminada la redacción de la Historia de los Incas, esta fue sometida a una lectura pública ante cuarenta y dos de los descendientes - las llamadas panacas reales - de los doce Incas que habían gobernado el Tawantinsuyu, «desde la fábula, que los dichos yndios dizen de su creación, hasta el fin de lo que es ystoria de los yngas» ${ }^{6}$, dejando fuera los apartados correspondientes al poblamiento de las Indias. La Ffee de la Prouança y Verificacion, como se denominó esta certificación, duró tres días y tuvo por objetivo que las panacas enmendasen o corrigiesen las partes de la historia que les parecían contrarias a la verdad, de acuerdo a lo declarado por el propio Sarmiento.

La Historia de los Incas permaneció inédita hasta fines del siglo XIX, no obstante lo cual existía evidencia documental que sugería que Sarmiento había escrito una crónica sobre los Incas y que esta había sido enviada desde el Perú hacia España ${ }^{7}$. El lingüista Wilhelm Meyer fue el responsable de despejar las dudas sobre su eventual existencia, al encontrar el manuscrito en la biblioteca de Göttingen bajo el nombre de Segunda parte de la Historia General llamada Indica. Pocos años después se sucedieron en forma casi simultánea dos ediciones: la primera fue publicada por Richard Pietschmann en 1906, con una introducción y notas a pie de página en alemán; y la segunda, que en realidad constituía una traducción de la crónica al inglés, publicada por Clements Markham en 1907 junto a una introducción y a un texto adicional: La ejecución del Inca Tupac Amaru de Baltasar de Ocampo.

La publicación de la Historia de los Incas abrió la posibilidad de acceder a una visión del pasado incaico opuesta a la transmitida hasta entonces por los Comentarios Reales del Inca Garcilaso, dividiendo a los eruditos de la época en dos bandos: de un lado los garcilacistas o hispanofóbicos, como los llamara Roberto Levillier, entre los cuales figuraban Clements Markham, José de la Riva Agüero y Hans Steffen; y de otro los que defendían la versión de Sarmiento y la administración toledana a la que representaba, entre los cuales

5 Castro, 2010: 1-2.

6 Sarmiento de Gamboa, 1942: 194.

7 En el Archivo de Indias, por ejemplo, existía una carta del virrey Toledo a Felipe II en la que este le anunciaba el envío de la crónica y de unos paños que la acompañaban, en los cuales estaba pintada la historia de la sucesión de los Incas representados junto a sus mujeres legítimas. También existía una carta del propio Sarmiento en que se decía autor de esa crónica. Esta evidencia documental, más las trazas que había utilizado Antonio de Herrera para elaborar la portada de su Década $V$, habían llevado a Marcos Jiménez de la Espada a suponer que esa historia existía, aunque sin que se supiese su paradero. Morales, 1932: 120. 
estaban Roberto Levillier y Raúl Porras Barrenechea, que responsabilizaba a Garcilaso de ser el «creador de un imperio manso e idílico», siendo la suya la visión de las «ñustas vencidas y de los parientes seniles y plañideros después de la conquista». Sarmiento, en cambio, representaba «la versión masculina del imperio incaico, con una moral de vencedores... una auténtica rapsodia de los tiempos heroicos» ${ }^{8}$.

Garcilaso y Sarmiento no solo transmitieron versiones opuestas del Incario sino también respecto a la figura del virrey Toledo y su administración, puesto que en los Comentarios Reales se le responsabilizaba de la ejecución de Tupac Amaru, ordenada por el propio virrey algunos meses después de la certificación a la que había sido sometida la crónica de Sarmiento. Según Garcilaso, Felipe II había reprochado a Toledo a su regreso a España la muerte del último inca, diciéndole en breves palabras «que se fuesse a su casa, que su Magestad no le auia embiado al Perú, para que matare Reyes, sino que siruiesse a Reyes $»^{9}$. La ejecución de Tupac Amaru se convirtió en un tema central en el debate académico de la época, en gran medida porque los garcilacistas como Markham vieron en la desaprobación del rey a la gestión toledana la posible causa de que la Historia de los Incas no hubiese sido publicada durante el siglo XVI ${ }^{10}$.

De la mano de las críticas a la administración toledana, otro de los temas más debatidos a partir de la publicación de la Historia de los Incas se relacionó con la probidad de la Ffee de la Prouança, dado que documentación paralela a la crónica revelaba que las observaciones que las panacas reales habían hecho a la historia narrada por Sarmiento no siempre habían sido incorporadas al documento por los intérpretes de la certificación. Por ejemplo, los descendientes de Huayna Capac se habían mostrado molestos por la utilización del término tiranía utilizado por la crónica para referirse al gobierno de los Incas, en respuesta de lo cual uno de los funcionarios virreinales les había explicado que «no se maravillasen de ello porque el Rey de Castilla tenía muchos reinos de otros ganados por fuerza de armas, y que también los había tomado como los Incas, y que no se enojasen por haberles dicho que

8 Porras Barrenechea, 1963: 153.

9 Garcilaso de la Vega, 1617: 299.

10 Por ejemplo, Markham suponía que con la Historia de los Incas había sucedido algo análogo a la prohibición que Carlos V había impuesto al Tratado sobre las justas causas de la guerra contra los indios de Juan Ginés de Sepúlveda: «It is right to say that Philip never seems to have endorsed the argument of his Viceroy, while his father prohibited the circulation of a book by Dr. Sepúlveda wich contained a similar argument; nor was the work of Sarmiento published». Markham, 1907: XX. 
no eran reyes, sino tiranos» ${ }^{11}$. No solo eso, sino que también el encargado oficial de la lectura de la crónica ante las panacas reales - Gonzalo Gómez Jiménez- afirmaba tiempo después de la Prouança que había sido obligado a cambiar las declaraciones de los ayllus reales, alterando varios conceptos y acomodándolos a los intereses del propio virrey ${ }^{12}$. Estos antecedentes enfrentaron nuevamente a los partidarios y los críticos de la Historia de los Incas, al punto que David Brading llegó a calificar la Prouança como una «siniestra farsa $»^{13}$, visión que contrastó con la de Levillier que se refirió a ella como una «junta histórica», concebida y ejecutada por un hombre que sabía someter las respuestas recibidas a las críticas de los testigos ${ }^{14}$.

Más allá de si Felipe II en efecto prohibió la impresión de la crónica o de si el virrey Toledo omitió las enmiendas que las panacas reales efectuaron al manuscrito de Sarmiento durante la certificación, lo cierto es que la Historia de los Incas constituye una crónica eminentemente política, que procuró demostrar la ilegitimidad de los gobernantes incas con el fin de revestir al dominio hispano de un marco legal que asegurara los plenos derechos de la Corona en los Andes. El presente artículo tiene por objetivo explorar este componente político de la crónica desde una perspectiva complementaria a la filiación toledana, que desborda las fronteras del virreinato y que la emparenta con la línea universalista de las historias generales peninsulares a través de un nuevo elemento: su relación con la Antiquitatum Variarum de Annio de Viterbo, una colección de textos espurios que constituyó una de las autoridades más recurrentes de los primeros capítulos de la Historia de los Incas. Las invenciones de Annio de Viterbo formaron parte de la línea oficial de representación del pasado impulsada por los Reyes Católicos en el contexto de la unificación de los reinos peninsulares a fines del siglo XV e identificaron a Túbal, uno de los nietos de Noé, con el fundador de la monarquía hispánica de la cual Fernando e Isabel se proclamaban herederos. En la Historia de los Incas es Túbal, o alguno de sus descendientes, el primer habitante no solo de España sino también de las Indias, poblamiento que Sarmiento hizo posible incorporando a su relato el continente platónico de la Atlántida.

11 Este testimonio está contenido en una carta del Padre Juan de Vera al Rey fechada en abril de 1572 y el responsable de tal afirmación fue el Doctor Loarte, alcalde de la corte que se hallaba presente durante la certificación. Levillier II, 1935: CVII.

12 Morales, 1932: 105.

13 Brading, 1991: 164.

14 Levillier I, 1935: 292. 
El poblamiento de Las Indias SEgún SARMiento

Los cinco primeros capítulos de la Historia de los Incas tratan acerca del origen de los indios del Perú y en ellos Sarmiento explica cómo las Indias fueron pobladas en tres ocasiones diferentes, por diversas rutas y en distintas épocas. El autor describe con bastante exactitud, en parte por su condición de navegante, las rutas involucradas en sus hipótesis de poblamiento teniendo en mente, tal como él mismo lo señala, el mapa que acompañó las múltiples ediciones de la Geographia de Ptolomeo que se imprimieron a partir del siglo XVI. Dado que las exploraciones marítimas habían demostrado que Ptolomeo en ocasiones estaba equivocado, Sarmiento tuvo la cautela de advertir al lector de los nuevos descubrimientos, adaptando la Geographia a los nuevos conocimientos que se habían desarrollado a partir de las empresas marítimas de España y Portugal ${ }^{15}$.

El más reciente de estos poblamientos correspondía al de las naciones de Esdras o tribus perdidas de Israel, cuyo paradero Sarmiento situaba en una «tierra longincua, que nunca habitó el género humano» ${ }^{16}$. Las doce tribus de Israel habían sido deportadas de Jerusalén tras la conquista de la ciudad por el Imperio Babilonio, retornando cuando este cayó en manos de los persas alrededor del siglo VI AC. Pero para entonces, de acuerdo a los libros veterotestamentarios de Esdras y Nehemías, solo dos de las doce tribus volvieron, permaneciendo el paradero de las restantes diez desconocido. La alusión a la tierra distante que hace Sarmiento proviene de un libro apócrifo conocido como Esdras IV o el Apocalipsis de Esdras, que circuló durante toda la Edad Media junto a los libros de Esdras y Nehemías pero que fue eliminado de la lista de libros canónicos del Antiguo Testamento durante el Concilio de Trento. Esdras IV narra en un tono escatológico una serie de visiones relacionadas con el fin de los tiempos, época en que el Altísimo regresaría acompañado de las diez tribus perdidas que se habían establecido en una región en donde nunca había habitado el género humano, más allá de las entradas del río Éufrates. Las tribus habían escogido para vivir un lugar tan lejano porque deseaban observar sus preceptos, los mismos que no habían guardado en su propia tierra, lejos de los gentiles y su religión ${ }^{17}$. Este destino había sido infructuosamente buscado por viajeros y navegantes en los confines del mundo imaginado durante toda la Edad Media, de modo que cuando las Indias entraron al imaginario europeo parecía bastante probable que el paradero de las

\footnotetext{
15 Sarmiento de Gamboa, 1942: 36.

16 Ibidem: 47.

17 Esdras IV, 13: 39-47.
} 
tribus perdidas estuviese en algún lugar del Nuevo Mundo y que, en consecuencia, al menos una parte de sus habitantes tuviesen ancestros judíos. Entre los cronistas que también plantearon la posibilidad de que las tribus perdidas se hubiesen establecido en las Indias está fray Diego Durán, que en su Historia de las Indias de Nueva España y Islas de Tierra Firme señalaba que los indios no obstante ignorar su origen, siempre concordaban en que habían llegado desde tierras extrañas tras padecer hambre, sed y desnudez, características propias de los judíos en el imaginario medieval ${ }^{18}$.

Según Sarmiento, las tribus habían caminado por el río Éufrates hasta llegar a Persia alcanzando el mar Índico a través de la península de Catígara, que se ubicaba al extremo oriental meridional del mapa de Ptolomeo, a nueve grados al sur de la equinoccial. En la geografía de Ptolomeo, la parte sur de Catígara estaba unida a una gran superficie de tierra que por su parte occidental se fusionaba con la costa oriental de África, de modo que el océano Índico quedaba cerrado por todas sus costas. Con la navegación magallánica se demostró que el océano Índico no constituía un mar interior y que, en consecuencia, existía una salida hacia el oriente de Catígara mediante la cual era posible alcanzar el Mar del Sur. No obstante, los nuevos descubrimientos no descartaron la existencia de la gran extensión de tierra meridional presente en el mapa de Ptolomeo, identificándola con la costa norte de la Tierra del Fuego avistada por Magallanes y su tripulación. Suponiendo que se trataba de un continente separado de los demás, en los mapas de la época comenzó a ser representada como la Terra incógnita al austro, un extenso territorio a través del cual Sarmiento proponía que las tribus perdidas habían cruzado desde Asia a las Indias, continuando el viaje que habían iniciado en Persia. Desplazándose a través de la Terra Australis en dirección este u oeste habían llegado hasta el Estrecho de Magallanes para luego cruzarlo y avanzar hacia el norte del continente indiano ${ }^{19}$.

18 Durán I, 1867: 2

19 Sarmiento, 1942: 36. La posibilidad de que el océano Índico no constituyera un mar cerrado tenía sus orígenes en los viajes de Marco Polo que, supuestamente, había retornado a Europa navegando por las costas orientales de Asia y penetrando en el océano Índico a través de un paso marítimo desconocido. La búsqueda de este paso alentó las navegaciones de Colón y Vespucio, entre otros, quienes supusieron que las costas orientales del Nuevo Mundo correspondían, en realidad, a las costas orientales de Asia. Vespucio intentó encontrar este paso a través de la península de Catígara, que en el mapa de Ptolomeo cerraba el océano Índico en su extremo más oriental, tal como queda expresado en una carta dirigida a Lorenzo de Medici con fecha 18 de julio de 1500: la «mia intenzione era di vedere si potevo volgere uno cavo di terra, che Ptolomeo nomina in Cavo di Cattegara, che e giunto con il sino Magno». O’Gorman, 2006: 146. 
La idea de que una gran masa de tierra se situaba en la parte más meridional del hemisferio austral tenía sus orígenes en Aristóteles y Eratóstenes, quienes suponían que debía existir un balance entre las dimensiones de la tierra en el hemisferio norte y en el sur. Este postulado fue debatido y desautorizado por los apologetas cristianos medievales pero gracias a las múltiples ediciones de Ptolomeo y a las sucesivas exploraciones europeas al sur del continente americano, la Terra Australis se incorporó al imaginario de los exploradores como un territorio descubierto pero inexplorado ${ }^{20}$. No es extraño, por ende, que en su Miscelanea Antártica Miguel Cabello Valboa planteara una hipótesis similar a la de Sarmiento, pero suponiendo que había sido la orden militar de los Nayres provenientes de la India oriental los que habían cruzado al Nuevo Mundo a través de la Terra Australis, y no las tribus perdidas como en la Historia de los Incas ${ }^{21}$.

El segundo de los poblamientos planteados por Sarmiento correspondía al de Ulises, que tras pelear en la guerra de Troya y edificar Lisboa en Lusitania había probado «su ventura por el mar atlántico océano, por donde agora venimos a las Indias, y desparesció, que jamás se supo después que se hizo» ${ }^{22}$. Sarmiento, siguiendo a Dante Aligero, proponía que Ulises había llegado a Yucatán y Campeche en Nueva España, deducción que obtuvo derivando etimológicamente el náhuatl teotl del griego teo, ambas partículas utilizadas para significar dios.

En la lógica de Sarmiento, sin embargo, el carácter fundacional del primer poblamiento hacía de este el más importante, puesto que ligaba las Indias a los orígenes mismos de toda la humanidad. Sus protagonistas habían sido los descendientes de Túbal, nieto de Noé a través de su hijo Jafet, quienes después del Diluvio Universal habían cruzado a las Indias por la Atlántida, el gran continente de los diálogos Timeo y Critias de Platón. En el esquema geográ-

${ }^{20}$ La expresión «territorio descubierto pero inexplorado» proviene de la inscripción que Oroncio Fine, cartógrafo francés del siglo XVI, incorporó en su mapa de la Terra Australis de 1531: «recenter inventa sed nondum plene cognita». El mapa de Fine está compuesto de dos planos, cada uno de los cuales corresponde a una representación del orbe visto desde el polo septentrional y el meridional, teniendo como eje el círculo ártico y el antártico, respectivamente.

21 Hablando del recorrido que los crueles Nayres realizaron por Asia antes de llegar a las Indias, Cabello Valboa dice: «pasaron á la segunda Jaua (por ser lo menor en todo) de alli les parecio bolverse hacia el Norte, por no hallarse poderosos para entrar a mostrarse valientes con la tierra Austral, que era ya tenida por firme (ó a lo menos en dubda si era Ysla)... esta es la que an descubierto los Portugueses sobre el cabo de buena esperanza, a quien llaman tierra de vista, y por el estrecho de Magallanes le llaman tierra de fuego y sus naturales Lucaht». Cabello Valboa, 1951: 187 y ss.

22 Sarmiento de Gamboa, 1942: 46. 
fico de Sarmiento, la Atlántida y las Indias habían formado parte de un solo continente, al cual también habían pertenecido otras islas del océano Atlántico como, por ejemplo, las Canarias. Los descendientes de Túbal habían cruzado a las Indias desde el Puerto de Santa María en Cádiz, que estaba tan próximo a la Atlántida que se podía atravesar por una tabla desde un lado al otro $^{23}$.

La integración de la Atlántida a la geografía de Ptolomeo fue una innovación del propio Sarmiento, cuya ausencia en el mapa de Ptolomeo es justificada por el autor aclarando que para entonces la isla ya se había hundido, perdiéndose la memoria de ella. La recuperación de la historia de la Atlántida durante el humanismo se debió en gran medida a la traducción al latín que del diálogo Critias había realizado a fines del siglo XV Marcelo Ficino, contexto en el que deben entenderse las palabras de Sarmiento cuando dice que no obstante la antigüedad de esta historia, su enseñanza era nueva entre los cosmógrafos de su época ${ }^{24}$. Con respecto a la desaparición de la mitad atlante de las Indias, Sarmiento señalaba que había sido a consecuencia de un gran diluvio ocurrido en el siglo XIV AC, de acuerdo a sus propios cálculos cronológicos ${ }^{25}$. Testimonio de este diluvio había sido el gran cieno que en el lugar del hundimiento se había formado, haciendo innavegable el océano y perdiéndose, por ende, todo el contrato y el comercio con las Indias occidentales desde entonces ${ }^{26}$.

Sarmiento no fue el único que planteó la posibilidad del poblamiento atlante de América, siendo Agustín de Zárate y Francisco López de Gómara dos de los cronistas que también siguieron la historia de Platón. Mientras el

23 «¿La cual, quién duda, que, estando tan cerca de España (la Atlántida), que según fama común Cáliz solía estar tan junta con la fierra (sic) firme por la parte del puerto de Santa María, que con una tabla atravesaban como por puente de la isla a España, sino que sería poblada aquella tierra de los pobladores de España, Tubar y sus descendientes, y también de los pobladores de África, cuya vecina era?». Sarmiento, 1942: 42.

24 Sarmiento, 1942: 37.

25 «la asolación de la isla Atlántica... debió suceder en el tiempo en que Aod gobernaba el pueblo de Israel 1320 años antes de Cristo, y de la creación 2162 años, según Hebreos». Sarmiento, 1942: 45.

${ }^{26}$ La idea de que más allá de las columnas de Hércules el océano Atlántico constituía un gran pantano arranca de Platón mismo y estaba ampliamente extendida durante la Edad Media. En el Viaje de San Brandán (S. XII), se lee: «Muchos tiempos llevan los viajeros recorriendo la mar, con larga singladura, pero sin ver tierra hacia ningún rumbo. Les falla el viento, los víveres les llegan a faltar, crece el hambre y la acuciante sed, y la mar se ha quedado tan quieta y espesa que su navegación se hace muy penosa: se ha vuelto fangosa como una marisma, hasta tal punto que temen estancarse. Dios los ayuda a salir, con una fuerte brisa...». Benedeit, 2002: cap XVII. 
primero en su Historia del descubrimiento y conquista del Perú propuso que la Atlántida correspondía a una isla distinta de las Indias, el segundo en su Historia General de las Indias planteaba una idea similar a la de Sarmiento, en el sentido de que también consideró que la Atlántida y el Nuevo Mundo habían conformado un solo continente ${ }^{27}$. De otra parte, el poblamiento atlántico también tuvo detractores, entre los cuales el más célebre fue José de Acosta, quien en una conocida sentencia de su Historia Natural y Moral de las Indias calificó la historia de la Atlántida como un cuento que no se podía contar sino a muchachos y viejas ${ }^{28}$. Con menos ahínco, Antonio de Herrera y Tordesillas recordaba en la Historia General de los hechos de los castellanos en las islas i tierra firme del mar oceano que nadie había tenido noticia clara de la Atlántida antes del descubrimiento de las Indias y que, en consecuencia, estas interpretaciones eran posteriores a la hazaña de Colón ${ }^{29}$.

Aunque Acosta y Tordesillas coincidieron en su crítica ante la posibilidad del poblamiento atlante de las Indias, nadie en el siglo XVI cuestionaba que la dispersión de la humanidad por el mundo se había llevado a cabo después del Diluvio Universal, que constituía el otro pilar de la argumentación de Sarmiento. En términos prácticos, esto significaba que todos los pueblos, no importando el lugar del mundo en el que estuviesen, debían tener como fundador a alguno de los descendientes de los tres hijos de Noé: Sem, Cam o Jafet. En el caso de las Indias, para las que la tradición clásica o medieval no había establecido ningún ancestro bíblico, la incógnita acerca de quién había sido su primer poblador permaneció vigente hasta bien entrado el siglo XVIII, cuando los trabajos de Buffon y James Hutton plantearon por primera vez que

27 Zárate no comprendía «porque se tenga dificultad a entender que por esta via ayan podido passar al Peru muchas gentes, assi desde esta grande ysla Athlantica, como desde las otras yslas», pues él mismo había observado en el Perú costumbres y ceremonias como las descritas por Platón para la Atlántida. Zárate, 1965: 8-11. López de Gómara, en tanto, dice que «no ay para que disputar, ni dudar, de la ysla Atlantide, pues el descubrimiento, y conquistas de las Indias, aclaran llanamente lo que Platon escriuio de aquellas tierras, y en Mexico llaman ala agua atl: vocablo que parece, ya que no sea, al dela ysla. Assi que podemos dezir, como las Indias son la ysla y tierra firme de Platon». López de Gómara, 1554: 294 $294 \mathrm{v}$.

28 «Sea como quisieren, haya escrito Platón por historia o haya escrito por alegoría, lo que para mi es llano, es que todo cuanto trata de aquella isla, comenzando en el diálogo Timeo y prosiguiendo en el diálogo Cricia, no se puede contar en veras, si no es a muchachos y a viejas». Acosta, 2006: 66.

29 «...i que la gran Isla por donde se pasaba a las otras, se llamaba Atlantia, i que las otras Islas son las de Barlobento, i Sotovento; i la Tierra-firme, el Peru; i el mar verdadero, el del Sur, por su grandeça. Pero cierta cosa es, que nadie tuvo noticia clara; i si alguno huvo, fueron rastros, i vislumbres, interpretadas despues del Descubrimiento». Herrera I, 1729: 2. 
la tierra tenía una antigüedad mucho mayor que la estipulada en la cronología bíblica $^{30}$. Siguiendo el modelo de narración de las historias generales europeas, Sarmiento y otros cronistas de los siglos XVI y XVII adoptaron el Diluvio General como punto de partida de sus relatos, asumiendo que el poblamiento de las Indias había sido posterior al del Viejo Mundo ${ }^{31}$. Felipe Guaman Poma de Ayala, por ejemplo, en la Nueva coronica y buen gobierno insistió reiteradamente en que toda la humanidad andina descendía de Noé, con excepción del segundo linaje de incas idólatras inaugurado por Manco Ca$\operatorname{pac}^{32}$.

Aunque, como es de suponer, los indígenas no tenían memoria del Diluvio General, ni del arca, ni de Noé, a lo largo del virreinato existían relatos orales de matriz andina sobre inundaciones pasadas, que también estaban asociados a los orígenes de los tiempos y que variaban de una región a otra. En las crónicas, es frecuente encontrar opiniones diversas en torno a si estos relatos correspondían al Diluvio Universal o a algún otro particular, puesto que a través de la literatura clásica y cristiana también se habían transmitido testimonios de inundaciones locales, la mayoría de ellas tomadas de la tradición griega y latina. Cieza en la Parte primera de la crónica del Perú recogió uno de estos relatos entre los Guancas de Jauja y los naturales de Chucuito en el Collao, pero dadas las diferencias con el relato bíblico - en esta historia sobrevivían mujeres y niños refugiados en cuevas - concluyó que se trataba de un diluvio particular, como el que había sucedido en Tesalia, y que los indios no tenían memoria del Diluvio Universal ${ }^{33}$.

30 Cohn, 1999: 101-102.

31 El ya mencionado Antonio de Herrera, por ejemplo, suponía que si el Arca había encallado en Armenia, que estaba situada en el hemisferio norte, necesariamente las Indias habían sido pobladas después del Viejo Mundo: «Muchos han deseado saber de donde pasaron los primeros habitadores del otro Emisferio, i no hay duda sino que pasaron de el Nuestro, pues nunca huvo mas de vna Arca de Noè». Herrera I, 1729: 9.

32 Guaman Poma menciona más de una vez que «del multiplico de los dichos españoles que trajo Dios a este reino de las Indias, los que salieron de la arca de Noé del diluvio después que multiplicó, estos dichos por mandado de Dios derramó en el mundo... estos dichos indios se llamaron Uariuiracocha runa porque descendió de los dichos españoles, y así le llamaron Uiracocha; de esta generación comenzaron a multiplicar y la descendencia y multiplico, después a éstos llamaron dioses y lo tuvieron así» Guaman Poma, 2004: 49. También es conocida la representación que Guama Poma hace del arca de Noé, en la que dibuja una llama en una de las ventanas de la embarcación. Guama Poma, 2004: 24.

33 «Creer que hubo algún diluvio particular en esta longura de tierra como fue en Tesalia y en otras partes no lo dude el lector, porque todos en general lo afirman y dicen sobre ello lo que yo escribo y no lo que los otros fingen y componen: y no creo yo que estos indios tengan memoria del diluvio general, porque cierto tengo para mí ellos poblaron después de 
Por otro lado, en la medida en que el Diluvio había sido una catástrofe mundial, a lo largo del extenso territorio indiano debían haber quedado huellas físicas como testimonio de su magnitud, de modo que los cronistas interpretaron el paisaje andino en código bíblico, buscando vestigios de la inundación en el Perú. José de Acosta en su Historia Natural y Moral de las Indias se mostró cauto a la hora de pronunciarse al respecto, señalando que los rastros y señales que algunos atribuían a la gran inundación parecían más bien corresponder a uno de estos diluvios particulares, como el de Platón o el de Deucalión ${ }^{34}$. Cieza, en cambio, sugería que la laguna Titicaca se había formado como consecuencia del Diluvio General, puesto que consideraba que el caudal de los ríos que desaguaban en ella era insuficiente a la hora de explicar la gran cantidad de agua dulce que contenía ${ }^{35}$.

Si bien el relato del Diluvio Universal también constituyó el punto de partida de la Historia de los Incas, la particularidad de Sarmiento radica en que su versión presenta algunas variantes respecto a la transmitida por Génesis 7-8: en primer lugar, el cronista precisa los nombres de las mujeres que iban a bordo del arca, agregando que Terra o Vesta - la esposa de Noé- había sido la responsable de encender el primer fuego como sacrificio después de la inundación; en segundo, en su relato Noé es un gigante que repobló el mundo embarcándose en unas galeras en el Ponto Euxino (mar Negro) y que recorrió todo el mar Mediterráneo fundando colonias y dividiendo la tierra entre sus hijos; por último, Sarmiento también ofrece una detallada cronología de esta navegación afirmando que Nemrod, uno de los descendientes de Noé a través de Cam, había fundado Babilonia a 130 años del Diluvio General. Del mismo modo, en la Historia de los Incas es Túbal, el nieto de Noé, el primero en cruzar a las Indias desde Europa, una vez concluido el Diluvio.

haber pasado y haber habido entre los hom[bres la división de las] lenguas en la torre de Babel». Cieza de León, 2005: 302-303.

34 «Hay entre ellos comúnmente gran noticia y mucha plática del Diluvio; pero no se puede bien determinar si el diluvio que éstos refieren, es el universal que cuenta la Divina Escritura, o si fue alguno otro diluvio o inundación particular de las regiones en que ellos moran; más de que en estas tierras, hombres expertos dicen que se ven señales claras de haber habido alguna grande inundación, yo más me llego al parecer de los que sienten que los rastros y señales que hay del diluvio, no son del de Noé, sino de alguno otro particular como el que cuenta Platón, o el que los poetas cantan de Deucalión». Acosta, 2006: 70-71.

35 «Querer yo decir cómo está reclusa tanta agua en aquella laguna y de dónde nace, no lo sé, porque puesto que muchos ríos y arroyos entren en ella, paréceme que de ellos solos no bastaba a se hacer lo que hay, mayormente saliendo lo que de esta laguna se desagua por otra menor que llaman de los Augalas. Podría ser que del tiempo del diluvio quedó así con esta agua que vemos, porque a mi ver si fuera ojo de mar, estuviera salobre el agua y no dulce». Cieza de León, 2005: 261. 
Ninguno de estos detalles están presentes en el relato bíblico, a pesar de que Sarmiento expresamente señale que así lo muestran «las divinas letras» ${ }^{36}$. En definitiva, aquí sus fuentes son Xenofonte, Filón y Beroso, tres autores que pertenecían a la obra Auctores Vetustissimi, vel Opera Diversorum Auctorum de Antiquitatibus Loquentium cum Commentario eiusdem Joh. Annii. Chronographia Etrusca et Italica. De Novem Institutionibus Etruscis. Quadraginta Quaestiones. De Primis Temporibus et Regibus Primis Hispaniae, una compilación de textos espurios publicados por Annio de Viterbo, uno de los más célebres falsarios de la historiografía española.

\section{AnNio de Viterbo y su Versión del Diluvio General}

Annio de Viterbo - también conocido Johannes Annius, Giovanni Nanni, Giovanni Viterbensis, el Pseudo-Beroso o Jacobo Annius- fue un famoso fraile dominico que formó parte de la curia de Alejandro Vl, en donde llegó a ocupar el cargo de Maestro del Sacro Palacio, cuya principal función era la de examinar, corregir y aprobar las obras que habían de imprimirse en Roma. Allí, se hizo conocido a partir de la publicación de un tratado en el que proponía la organización de una cruzada en defensa de la cristiandad, amenazada por el avance del imperio Turco sobre Constantinopla ${ }^{37}$. También había publicado unos comentarios sobre el Apocalipsis, en los que Mahoma era identificado como el Anticristo, no obstante lo cual su obra más conocida fue la Antiquitatum Variarum, nombre con el que se conoció la colección de trece textos espurios que Annio de Viterbo decía haber encontrado casualmente en la Bética y en diversos lugares de Italia, cuyos autores eran de origen caldeo, egipcio, griego y latino ${ }^{38}$.

La Antiquitatum fue publicada por primera vez en 1498, acompañada de extensos comentarios de la propia pluma de Annio de Viterbo como era - al

36 Sarmiento, 1942: 41-42.

37 Caro Baroja, 1992: 51.

38 De los trece autores que Annio incorporó a la Antiquitatum solo uno era auténtico: Propercio. Los doce restantes eran Beroso Caldeo, Manetón, Metasthenes, Filón, Arquíloco, Jenofonte (no el historiador), Antonino Pio, Marco Catón, Fabio Píctor, Mirsilio de Lesbos, Cayo Sempronio y Mario Aretio. La supuesta procedencia de estos textos era variada: de unos sepulcros escondidos en la Bética, al sur de España, territorio conquistado recientemente por los Reyes Católicos; de manos de dos dominicos armenios en Génova en 1474; de la ciudad de Mantua, en la región de la Lombardía en Italia; y de un libro llamado Colectanea Vetusta, que un también supuesto Guillermo de Mantua había escrito en 1315. Caballero López, 11/12 (La Rioja, 2004): 91. 
fin y al cabo - todo el libro. De los trece textos inventados por Annio de Viterbo, dos trataban ampliamente sobre el Diluvio y el poblamiento del mundo: De Equiuocis de Xenofonte y De Antiquitatibus de Beroso el caldeo. Mientras Xenofonte correspondía a una invención del propio Annio, Beroso había sido un sacerdote y astrólogo caldeo del siglo III AC, contemporáneo a la traducción de la Tora de los LXX en Alejandría y autor de las Antigüedades de Babilonia, un completo recuento de la historia de Babilonia desde la creación del mundo hasta el reinado de Alejandro Magno. De las Antigüedades del verdadero Beroso, perdidas ya desde la Antigüedad tardía, solo se conocían los fragmentos que habían sobrevivido a través de la tradición clásica, principalmente a partir de las Antigüedades Judaicas de Flavio Josefo. Estos fragmentos se introdujeron en las historias medievales, con algunas variantes, a través de la Historia Scholastica de Petrus Comestor y de la General Estoria de Alfonso X, no obstante lo cual Annio de Viterbo los modificó para que concordaran con el resto de sus invenciones, tejiendo una compleja red de historias y cronologías en las que combinó su vastísima erudición y su propia imaginación.

La importancia de las Antigüedades del verdadero Beroso radicaba en que ofrecían una versión de los orígenes de la humanidad que no contradecía la historia transmitida por el Libro del Génesis, dado que ambos relatos compartían varios elementos en común. Uno de ellos era la descripción de un diluvio muy parecido al de Noé, similitud que autores clásicos y cristianos habían atribuido a que tanto Beroso como Abraham eran de origen caldeo y, en consecuencia, debían haber bebido de la misma fuente. Por ende, la versión de Beroso era tan antigua como la Biblia misma, autoridad que Annio de Viterbo aprovechó para escribir en su nombre un detallado recuento de lo que había sido el poblamiento postdiluviano llevado a cabo por los descendientes de Noé, episodio que en Génesis 10 se caracteriza por ser breve, repetitivo e incompleto. Más aún, en el recuento bíblico la mayoría de los toponímicos mencionados habían resultado irreconocibles incluso para los primeros comentaristas del Génesis que, dando origen a una prolífica literatura al respecto, habían intentado ajustar el destino de la descendencia de Noé a los conocimientos geográficos de sus respectivas épocas ${ }^{39}$. Sin embargo, ninguno tuvo la trascendencia de la Antiquitatum, que se convirtió en una alternativa concreta para quienes buscaban dar cuenta de ese pasado oscuro y remoto de la Europa postdiluviana, poniendo a disposición de los autores humanistas un abundante repertorio de onomásticos y topónimos que les permitieron remon-

39 Braude, LIV/ 1 (Virginia, 1997): 108. 
tar los orígenes de sus ciudades a los inicios de la humanidad. El éxito de la Antiquitatum fue tal que entre 1498 y 1612 se sucedieron al menos diecinueve ediciones, con y sin los comentarios de Annio, siendo la más difundida en España la publicada en Amberes en $1552^{40}$.

El principio sobre el que se articuló el método del viterbense fue la construcción de genealogías que homologaban héroes de las más variadas tradiciones de la antigüedad con patriarcas bíblicos, alegando que se trataba de los mismos personajes, pero cuyos nombres habían variado de acuerdo a la lengua o el lugar en que habían sido registrados. Otra particularidad del método de Annio consistió en organizar cronológicamente las historias de los orígenes en torno a los sucesivos diluvios registrados en la Antigüedad, el primero de los cuales había sido el bíblico de Noé que, por supuesto, era el único de carácter universal. Los diluvios locales posteriores al de Noé habían sido cuatro, tal como quedaba de manifiesto en Equiuocis de Xenofonte. Después del Diluvio General, el segundo había tenido lugar en el Nilo en tiempos de Prometeo Egipcio, el tercero en el Ática en tiempos de Ogygio ático, el cuarto también en el Ática en tiempos de Deucalión y el quinto en la isla de Faros, en tiempos de la destrucción de Troya. De todos estos diluvios existían referencias, aunque solo fuesen muy breves, en autores como Aristóteles, Diodoro, Heródoto, Juvenal, Lactancio, Lucano, Solino y Servio, tal como señala el mismo Annio en el comentario a Xenofonte ${ }^{41}$.

El episodio del poblamiento del mundo después del Diluvio General al que se refiere Sarmiento en la Historia de los Incas corresponde en mayor medida al de Beroso el caldeo, que se convirtió en la más popular de todas las invenciones del viterbense. En el Beroso de Annio de Viterbo, Noé es el más virtuoso de los gigantes de la era prediluviana, que después de la inundación zarpó desde el Ponto Euxino en dirección al Mar Mediterráneo repartiendo las costas de Asia, África y Europa entre sus hijos Sem, Cam y Jafet y enseñando los principios de cosmografía que había aprendido antes del

40 Caballero López, 11/12 (La Rioja, 2004): 101.

41 «Hae sunt quinque inundationes, quas ab autoribus inuenio celebratas: quarum que prima terrarum fuit, aliae vero particulares: \& a prima ad uiltimam octincenti anni \& amplius, per certissimos annales Assyriorum colliguntur». Nanni, 1498: Iiiii [1r-2r]. La edición de la Antiquitatum que seguimos en el presente artículo corresponde a la primera edición impresa en Roma en 1498, en la versión digital disponible en la Biblioteca Nacional de España. Dicha impresión presenta errores de foliación, debido a que el orden originario de los fascículos fue alterado por el propio Annio de Viterbo con el objetivo de introducir al inicio del volumen la carta dedicatoria a los Reyes Católicos y al final de este el libro sobre las antigüedades de España. Caballero López, 11/12 (La Rioja, 2004): 98-99. 
diluvio a sus descendientes ${ }^{42}$. De los comentarios de Annio a Beroso también proceden el sacrificio ofrecido después de la inundación por Vesta, la esposa de Noé, o la fecha de la fundación de Babilonia por Nemrod, presentes en la Historia de los Incas ${ }^{43}$.

Junto con la descripción del poblamiento del mundo por Noé y su descendencia, Annio de Viterbo también incluyó en su obra un libro que no figura en todas las ediciones de la Antiquitatum y que fue incorporado tardíamente a algunas de las ediciones sucesivas: De primis temporibus et quatuor ac viginti regibus Hispaniae et ejus antiquitate, una lista comentada con los veinticuatro reyes que se habían sucedido en Hispania desde el Diluvio en adelante, el primero de los cuales había sido Túbal. En ella, Annio recopilaba e interpretaba para los Reyes Católicos las referencias a los monarcas hispanos contenidas en los autores inventados, completando el listado con el repertorio de reyes que en las historias generales de Hispania ya existían. De primis temporibus constituía una prueba de la antigüedad de la monarquía hispánica en el contexto de la historia universal, ya que arrancaba a 143 años del Diluvio Universal, apenas unos pocos años después de la fundación de Babilonia ${ }^{44}$. Y aunque la identificación de Túbal con el ancestro de los íberos tenía sus orígenes en las Antigüedades Judaicas de Flavio Josefo y había estado presente en toda la tradición medieval, en Annio de Viterbo este aparece convertido en el primer rey de Hispania, transformándose en el fundador de la institución monárquica de la cual los Reyes Católicos eran herederos ${ }^{45}$. La invención de un pasado legendario para la monarquía hispánica no era fortuito, en la medida en que fueron los Reyes Católicos a través de su embajador en la Curia romana quienes habían financiado la impresión de la Antiquitatum. Por esta razón Annio de Viterbo les dedicó la obra, introduciendo junto con

42 «(Noam) Ergo docuit principes coloniarum senissimus cosmographiam/ quam uiderat ante diluuium ut sciret quisque in quem locum suas colonias ducturus esset. Eo tempore ut Phylo Hebreus de multiplicato humano genere tradit/ ipse cum tribus filiis \& multis coloniis in pontum uenit/ \& ratibus circumlustrauit omne mare mediterraneum ostendens primo Sem litus omne Asiaticum/ a Tanai per Bosforum usque ad Nylum Egypti: Et Camesi a Nylo litus Aphricae usque in angustias occeani \& Gadium. Iapheto autem omne litus Europae a Gadibus usque Tanaim. Et singulis prouinciis circa litus dimisit primas colonias». Annius, 1498: Qiii [1r-1v].

43 «Post diluuium uero anno centesimo per totum sequens decennium conditae sunt prime coloniae singularum prouinciarum littorearum ut diximus. Babillonia uero cum post diluuium designata fuerit anno cxxxi ut dicit, patet quod non fuit prima quo ad tempus, sed dignitate edificii \& libidinis dominandi ut omnes notant». Annius, 1498: Qiii [1v].

44 Caballero López, 11/12 (La Rioja, 2004): 108.

45 Caro Baroja, 1992: 47. 
la lista de reyes hispanos una carta dedicatoria que, tal como la lista, fue anexada tardíamente al volumen.

El empleo de cronistas que emparentaran sus respectivos benefactores con héroes clásicos o postdiluvianos fue una característica común a las cortes europeas del siglo XVI, que buscaron en la invención de un origen bíblico o legendario la garantía de su antigüedad y abolengo ${ }^{46}$. En el caso de la Antiquitatum, al documentar la antigüedad de la institución monárquica, inauguró el desarrollo de una línea historiográfica oficial a través de la cual el proyecto gubernativo de unificación de la cristiandad de los Reyes Católicos aparecía representado como la culminación de un pasado en el que siempre había existido la monarquía. Fernando e Isabel potenciaron económicamente este proyecto aumentando el número de cronistas oficiales financiados por la Corona, los cuales gozaron de una serie de prerrogativas a cambio de cumplir con su responsabilidad política ante el rey ${ }^{47}$. Por otra parte, la Antiquitatum selló una alianza entre los Reyes Católicos y Alejandro VI, cuya procedencia también hispana fue interpretada como un símbolo de la grandeza y de las proyecciones imperiales de España, elegida para unificar la cristiandad y llevar el mensaje de Cristo a los confines del mundo ${ }^{48}$.

A pesar de su estatus oficial, varios detalles de la Antiquitatum dejaban en evidencia su falsedad, de modo que las denuncias en su contra no fueron pocas. En 1587 el arzobispo de Tarragona Antonio Agustín publicó sus Diálogos, en los que exponía cómo Annio también había falsificado y enterrado ciertas inscripciones en su Viterbo natal, con el fin de demostrar que la ciudad había sido fundada por Isis y Osiris. Otro de sus detractores fue el humanista portugués Gaspar Barreiros quien en 1561 publicó sus Censuras, dirigidas contra el falso Beroso y otras de las invenciones de Annio. La crítica de Ba-

46 La filiación entre monarquía y textos falsos fue bastante común en el contexto de los nacionalismos europeos del siglo XVI. Anthony Grafton, en su libro Falsarios y Críticos, recuerda el caso de Wolfgang Lazius, cronista al servicio de la corte de los Habsburgo, que hizo descender a esta casa dinástica de los adalides hebreos que se habían instalado en Viena después del diluvio. Grafton, 2001: 43.

47 Enrique García llama la atención sobre este rasgo político del cargo de cronista, subrayando que «el monarca buscaba desde el poder un servicio eficaz a su política oficial que fuera a la vez útil a la ciencia, de modo que bajo la máscara de ciencia y religión pudiera ofrecer una imagen convincente de su proyecto gubernativo». García, 19 (Cáceres, 2006): 128-134.

48 El obispo de Cartagena Bernardino López de Carvajal en su discurso de prestación de obediencia al papa Alejandro VI recordaba que se acababan de «descubrir otras islas desconocidas hacia la India, que con mucho son consideradas las más preciosas del mundo y se cree que por medio de mensajeros regios obedecerán en breve a Cristo». Fernández de Córdova, 28 (España, 2005): 307-311. 
rreiros se basaba en una escrupulosa comparación del falso Beroso y de los fragmentos que habían sobrevivido del verdadero, principalmente a través de Flavio Josefo. Por otro lado, Barreiros reparaba en el hecho de que era prácticamente imposible que un historiador caldeo estuviese al tanto de los pormenores del poblamiento europeo y africano después del diluvio, dado que estos territorios eran desconocidos incluso para autores posteriores a Beroso. Finalmente, la navegación mediterránea de Noé parecía bastante improbable, considerando los elementos técnicos que esta requería ${ }^{49}$. No obstante, Annio no tuvo la oportunidad de defenderse de sus críticos pues murió en 1502, apenas unos pocos años después de la publicación de la Antiquitatum.

Las historias relacionadas con los orígenes de España de Annio de Viterbo se filtraron a un gran número de crónicas hispanas, especialmente a las escritas por cronistas oficiales. En ocasiones, la referencia a su autoría se perdió por completo, sin que apareciese mención alguna a la Antiquitatum o a Annio de Viterbo. Tal es el caso de Chronographia o Reportorio de los Tiempos del cosmógrafo oficial Hieronimo de Chaves publicada en Sevilla en 1548, ampliamente difundida durante el siglo XVI y que fue utilizada por Guaman Poma de Ayala en la redacción del capítulo de las Edades del Mundo de la Nueva Coronica y Buen Gobierno. En su catálogo de los reyes de España «colegido de muchos y authenticos Authores», Chaves inicia su listado con Túbal, que había comenzado a reinar en España en el 2173 AC, prosiguiendo con el resto de los monarcas de la lista de Annio de Viterbo hasta Abidis, el número veinticuatro de la genealogía que había reinado a partir del $622 \mathrm{AC}^{50}$. Otro ejemplo de cómo el listado de reyes postdiluvianos de Annio de Viterbo se integró a este género sin una referencia explícita a su origen es la Cronología y Reportorio de la Razon de los Tiempos compuesta por el cosmógrafo y piloto mayor del rey Rodrigo Çamorano y publicada en 1594, en la que la sucesión de los reyes de España comienza con Túbal en el 1799 AM y termina también con Abidis, esta vez en vigésimo quinto lugar, en el $2898 \mathrm{AM}^{51}$.

Otros cronistas ligados a la corona que durante el siglo XVI siguieron al falso Beroso de Annio de Viterbo fueron Antonio de Nebrija, Lucio Marineo Sículo, Juan Ginés de Sepúlveda y Esteban de Garibay ${ }^{52}$. No obstante, el

49 Stephens, 119/ 1 (Baltimore, 2004): 205-212.

50 Chaves, 1584: 79r.

51 Çamorano, 1594: 383v-384v.

52 Antonio de Nebrija: Rerum a Ferdinando V et Elisabe Hispaniarum Regibus gestarum Decades II (1510); Lucio Marineo Sículo: De primis Hispaniae et aliarum regionibus cultoribus, incluido en la segunda edición de su De Rebus Hispaniae memorabilibus (1530); Juan 
seguidor de Annio que tuvo mayor repercusión en las crónicas posteriores fue Florián de Ocampo, cronista oficial de Carlos V y autor de la Cronica General de España publicada en 1543. Ocampo fue muy cauto y previsor respecto a las dudas que sabía podían ocasionar las invenciones del viterbense, de modo que dedicó parte de su prólogo a explicar las razones que lo habían llevado a incluir las historias de la Antiquitatum en su crónica. La primera era que Annio de Viterbo había dirigido «la publicacion de sus obras y su Beroso a tan esclarecidos Principes quanto fueron Don Fernando, y Doña Isabel nuestros Reyes y Señores naturales aguelos de vuestra Magestad» ${ }^{53}$, recordando una vez más el vínculo que unía a la Antiquitatum con la monarquía. La segunda razón era que no existía otra crónica que contuviera información sobre tiempos tan remotos, afirmación que debe entenderse en el contexto de la valorización de las fuentes antiguas que potenció el humanismo y sin la cual no se hubiese pensado en fabricarlas ${ }^{54}$. Desde este punto de vista, los falsarios fueron la consecuencia lógica y perversa de este movimiento, pues los humanistas consideraban que fabricar un texto era un sustituto legítimo para un documento ausente que debió haber existido y que faltaba por accidente ${ }^{55}$.

Otro cronista peninsular que siguió la Antiquitatum fue Anton Beuter, autor de la Primera parte de la Coronica General de toda España, y especialmente del Reyno de Valencia impresa por primera vez en 1546. Fue a través de Beuter que la historia de la navegación mediterránea de Noé y los cuatro diluvios locales de Annio de Viterbo llegaron a la Historia de los Incas, puesto que Sarmiento resumió el relato de Beuter adecuándolo al contexto de su propia historia ${ }^{56}$.

El modelo de poblamiento postdiluviano que Annio de Viterbo trazó para los primeros tiempos también se deslizó a otras crónicas de Indias, aunque de diversas maneras. Por ejemplo, Francisco López de Gómara, el mismo que había propuesto que la Atlántida y las Indias formaban parte de un solo continente, mencionó brevemente en su Historia General de las Indias la nave-

Ginés de Sepúlveda: De rebus gestis Caroli Quinti; y Esteban de Garibay: Compendio historial de las Crónicas y universal historia de todos los reinos de España (1571). Caballero López 11/12 (La Rioja, 2004): 116-117.

53 Ocampo, 1791: 50-51.

54 Wood (Connecticut, 2006): 22.

55 Córdoba, 30 (Toulouse, 1985): 249.

56 Aunque Sarmiento solo cita una vez a Beuter, y a propósito del ya mencionado viaje hacia occidente de Ulises, las referencias a Beroso, Xenophonte y Filón también provienen de él. El vínculo entre Beuter y Sarmiento fue puesto de manifiesto por Richard Pietschmann en la primera edición de la Historia de los Incas. Pietschmann, 1906: 16. 
gación mediterránea de Noé del que «llaman Beroso», aunque sin entregar mayores detalles acerca del viaje ${ }^{57}$. También en la Historia General y Natural de las Indias de Gonzalo Fernández de Oviedo la presencia de Annio de Viterbo es manifiesta y, más aún, protagónica: en ella Hespero, el duodécimo rey de España en genealogía de la Antiquitatum, es rey de las Indias, puesto que para Oviedo las Hespérides correspondían, en efecto, al Nuevo Mundo. En consecuencia, de acuerdo a sus cálculos las Indias pertenecían al señorío de España desde hacía 3.193 años, contando los 1.658 que según Beroso habían transcurrido entre el reinado de Hespero y el nacimiento de Cristo y los 1.535 que se habían sucedido desde este hecho hasta los tiempos de Ovie$\mathrm{do}^{58}$. Las implicancias políticas de los postulados de Oviedo - que en resumidas cuentas hacían de la llegada de Colón un re-descubrimiento - fueron puestas de manifiesto por David Brading y Franklin Pease, ya que asumir el dominio hispano de las Indias con anterioridad a 1492 implicaba que estas pertenecían por derecho antiquísimo a su majestad, haciendo innecesario el donativo papal de las bulas alejandrinas ${ }^{59}$.

Para el contexto andino, junto a Sarmiento de Gamboa el cronista que más de cerca siguió las falsificaciones de Annio de Viterbo fue el ya mencionado Miguel Cabello Valboa, que en reiteradas ocasiones incorporó sus historias y genealogías en su Miscelánea Antártica ${ }^{60}$. Pease también señala entre los herederos de la Antiquitatum a Antonio de la Calancha, Buenaventura de Salinas y Córdova, Bartolomé de las Casas, Gregorio García y Diego Andrés

57 «Mas el que llaman Beroso dize que Noè puso nombre a Africa, Asia, y Europa. Y las dio a sus tres hijos, Cam, Sem y Iafet, y que nauegò por el mar Mediterraneo diez años». López de Gómara, 1554: 15v.

58 «Assi las yslas que se dizen esperides y que señalan seboso y solino y plinio y ysidoro según esta dicho se deuen tener indubitadamente por estas indias: y auer seydo del señorio de España desde el tiempo de espero duodecimo rey della que fue según beroso escriue mil y seyscientos y cinquenta y ocho años antes quel saluador del mundo naciesse. Y porque al presente corren de su gloriosa natiuidad mil y quinientos y treynta y cinco años: siguese que agora tres mil y ciento y nouenta y tres años españa y su rey espero señoreauan estas indias o yslas esperides». Fernández de Oviedo, 1547: IIIIr. Pierre Vidal-Naquet, siguiendo a Gerbi, comenta que Carlos V hizo saber a Fernández de Oviedo su satisfacción por haber sabido que «desde hace tres mil ochenta años, estas tierras pertenecen al patrimonio real y que Dios, después de tantos años, las haya devuelto a su dueño». Vidal-Naquet también agrega que «toda esta argumentación deriva de un falsario célebre, Annio de Viterbo, que en Italia estaba a sueldo del rey de España». Vidal-Naquet, 2006: 71-72.

59 Brading, 1991: 52. Pease, 1995: 92.

60 Cabello Valboa se extiende ampliamente sobre el diluvio y el poblamiento del mundo por los descendientes de Noé sobre todo en la primera parte de su crónica, siguiendo y nutriendo las historias de Annio de Viterbo con las de otros autores clásicos y humanistas. Cabello Valboa, 1951: 11-80. 
de Rocha. Y aunque el Inca Garcilaso no lo citó directamente es probable que entre los libros de su biblioteca hubiese un ejemplar de Annio de Viterbo, inventariado bajo el título de Autor de barias antigüedades ${ }^{61}$. También un ejemplar de las múltiples ediciones de la Antiquitatum llegó hasta la biblioteca del extirpador de idolatrías Francisco de Ávila, que fue registrado en el inventario de esta bajo el nombre de Berrosso de antiquitatibus ${ }^{62}$.

\section{Conclusiones}

Los historiadores de principios y mediados del siglo XX abordaron la Antiquitatum Variarum desde una perspectiva crítica, enfatizando su condición espuria y convirtiéndola en el mejor ejemplo de cómo los horrores de la seudohistoria habían contaminado con sus fábulas y embustes los inicios de la ciencia histórica ${ }^{63}$. Del mismo modo, al identificar la presencia del viterbense en la Historia de los Incas de Pedro Sarmiento, los primeros estudiosos de la crónica tendieron a desestimar los capítulos relacionados con la descendencia de Noé y la Atlántida por considerarlos una herencia directa de las falsedades de la Antiquitatum, centrando su atención en la Prouança de Fe y en la impronta toledana del texto. En esta línea, Richard Pietschmann anotó los primeros capítulos señalando que procedían de las «chapucerías» (machwerken) y «explicaciones fantásticas» (phantastischen erläuterungen) del oscuro texto de Annio de Viterbo ${ }^{64}$, en tanto que Hans Steffen indicó que se trataban de «esposiciones mui fantasticas, mezcla de datos biblicos i de la mitolojia griega, tomados por la mayor parte de compilaciones de segunda mano i casi sin valor alguno» ${ }^{65}$, mientras que María Rosa Lida señaló que Sarmiento había poblado a América con los descendientes de Túbal «de su propia perversa imaginación ${ }^{66}$.

61 En el inventario de la biblioteca del Inca, Durand identificó dicho libro con el de Bernardo de Alderete Varias Antigüedades de España, África y otras provincias (1614). Sin embargo, Eugenio Asensio sugirió que en realidad correspondía a una de las ediciones de Annio de Viterbo que llevaba por título Antiquitatum Variarum Auctores (Lugduni, 1552 o 1560). Pease, 1995: 92 y 379-380.

62 Hampe, 1996: 96.

63 Dice Sánchez Alonso refiriéndose a Annio de Viterbo: «Esta lucubración del famoso dominico, en que se consolida y se eleva al número de veinticuatro la serie de reyes fabulosos iniciada por Túbal, influyó nefastamente por los errores afianzados con su autoridad y por lo que aficionó a la larga al cultivo de la seudohistoria». Sánchez Alonso I, 1947: 356.

64 Pietschmann, 1906: 16.

65 Steffen, CXXIX (Santiago, 1912): 1115.

66 Lida de Malkiel, 3 (Valencia, 1970): 35. 
Franklin Pease, por otro lado, excusó a los cronistas que habían incorporado las historias de la Antiquitatum en sus textos advirtiendo que los historiadores de aquellos años, a diferencia de los criterios historiográficos que se habían consolidado a partir del siglo XIX, no verificaban las informaciones y menos aún la credulidad que se les otorgaba a sus fuentes. La distinción que estableció entre el falso Beroso y las fuentes históricas más fiables llevó a afirmar a Pease, parafraseando a Dumézil, que cualquier insensatez, con tal que la bibliografía y las notas fuesen abundantes, era susceptible de ser integrada en el saber ${ }^{67}$.

Para los historiadores educados a la sombra del progreso, las fábulas y la imaginación eran evidencias de una humanidad superada, distinta de la moderna disciplina historiográfica que solo debía hacerse cargo de la historia «verdadera», es decir, de valor positivo. Esta actitud constituyó uno de los puntos más débiles de la crítica positivista y, junto con evidenciar su falta de conciencia de sí, contribuyó a cristalizar la idea de que los historiadores del siglo XX sabían «más y mejor» (besserwissen) que los antiguos ${ }^{68}$. Dentro de los antiguos, sin embargo, era posible rescatar a algunos que se habían destacado por su carácter moderno y racionalista, que no se habían dejado engañar por fábulas o falsarios y que, por supuesto, no creían en continentes imaginarios o en islas perdidas. En el contexto andino, José de Acosta se perfiló como el arquetipo del cronista cauto y crítico que, anticipándose a sus contemporáneos, había rechazado las fábulas de la Atlántida, del mismo modo que había hecho caso omiso a las historias de Annio de Viterbo ${ }^{69}$. En la misma línea, Pease señalaba que el Inca Garcilaso sobresalía como un historiador de calidad que se había apegado a fuentes más seguras, a pesar de que en su biblioteca se habían encontrado libros de «saber arcano», falsificados sobre la base de presuntos manuscritos egipcios ${ }^{70}$.

Las aprensiones de la crítica positivista respecto a las fábulas se deslizaron a enfoques disciplinarios más contemporáneos que heredaron la idea de que

67 Pease, 1995: 97.

68 Bernal, 1993: 127.

69 «No podían faltar quienes se opusieran a esas consideraciones con un espíritu racionalista destacablemente moderno para su época como es el caso del notable historiador jesuita Joseph de Acosta». Tord: 1999: 29. Hablando de las tesis hebreas del origen de los habitantes de las Indias, Jaime Borja señala que «Buena parte de los textos de Indias que se escribieron en la misma época buscaban estos orígenes, aunque Joseph de Acosta, al publicar en 1590 la Historia Natural y Moral de Indias, destrozó la teoría del origen judío del indio». Borja, 2002: 141. Cabe señalar, en todo caso, que la tesis del origen judío de los Indios ganó aún más adeptos durante el siglo XVII, en gran medida gracias a la publicación de Esperanza de Israel de Menasseh ben Israel.

70 Pease, 1995: 379. 
la historia debía hacerse cargo de relatos verdaderos, pero que desplazaron el componente ficcional presente en las crónicas de Indias ya no a los dominios de la seudohistoria sino al campo de lo verosímil, entendido como un discurso coherente y secuencial que podía ser formulado desde lo probable. Este tipo de análisis suponía que para el siglo XV no había existido una frontera definida entre la historia (verdad) y la ficción (verosímil) porque en español no existía una palabra para distinguir la historia de la novela larga ${ }^{71}$. Al respecto, es pertinente recordar que las narrativas históricas son estructuras complejas, en las que el componente ficcional y el real son parte de un mismo sistema, el de la representación histórica: independientemente de si el mundo es concebido como real o como imaginado, la manera de darle sentido es la misma. Las fábulas o falsificaciones, en consecuencia, no deben ser analizadas desde un universo ficcional paralelo a lo real, sino que deben ser entendidas en el contexto mismo de su producción ${ }^{72}$.

De otra parte, y tal como Paul Veyne ha señalado a propósito de los mitos griegos, el escepticismo es tan antiguo como las fábulas mismas, de modo que siempre han habido incrédulos, indóciles frente a la palabra del otro ${ }^{73}$. Abordar la discusión desde la perspectiva de sus críticos y privilegiar un linaje más racionalista de explicación histórica es una opción válida de análisis, pero en ningún caso puede considerarse como la única. Pierre Vidal-Naquet ha planteado, refiriéndose concretamente a la Atlántida, que si bien los historiadores son totalmente libres de elegir un enfoque racionalista de análisis, no pueden actuar como si estas fábulas no hubiesen existido, invisibilizándolas o relegándolas al dominio de lo fantástico o lo probable ${ }^{74}$.

En este sentido, una aproximación a las falsificaciones y a las historias ficcionales presentes en ellas ha sido propuesta por Mercedes García Arenal quien, a raíz de sus investigaciones sobre los Plomos del Sacromonte de Granada, ha planteado la necesidad de analizarlas centrándose en los fines que estas buscaron y en el contexto político en que estas se elaboraron, más allá de su factura espuria y de las dudas sobre su autoría. La falsificación de los Plomos del Sacromonte, por ejemplo, pretendía demostrar la antigüedad de las oligarquías moriscas granadinas en el contexto de la agudización de la

71 «Historia y ficción no tenían fronteras definidas. Las poéticas del siglo XV habían establecido algunas diferencias entre la prosa histórica y la de ficción, pero a finales del siglo XVI no había una clara delimitación entre una y otra, porque en español no había una palabra que sirviera para distinguir la novela larga de la historia: una y otra se designaban con el nombre de historia». Borja, 2002: 73-74.

72 White, 2003: 137-138.

73 Veyne, 1985: 65.

74 Vidal-Naquet, 2006: 113. 
política de expulsión de los musulmanes durante el gobierno de Felipe II, remontado su presencia en la península a los tiempos de Santiago Apóstol. Los autores de la falsificación pertenecieron a esa elite de moriscos acomodados que ya no contaban con el favor y las franquicias tributarias que la Corona les había ofrecido durante los casi cien años transcurridos desde la toma de Granada hasta la década de 1570 y que, en un intento por reivindicar sus derechos, elaboraron una serie de documentos y reliquias tendientes a probar que la presencia árabe en la península era tan antigua como la de cualquier cristiano viejo. No importa si la historia es inventada, lo importante es determinar con qué fines se inventó, qué consecuencias esta tuvo, quiénes la utilizaron, quiénes se la creyeron y por qué75.

Del mismo modo, pero en el contexto de los estudios andinos, el hallazgo en los años noventa de un manuscrito anónimo que atribuía la autoría de la Nueva Corónica y Buen Gobierno no a Felipe Guaman Poma de Ayala sino al cronista fantasma Blas Valera dejó en evidencia la necesidad de analizar las falsificaciones en el contexto de los deseos y expectativas del tiempo en que fueron creadas, tal como lo señalara Rolena Adorno. En este sentido, la figura de Blas Valera representa aquí el dux populi del pueblo andino, poseedor de un espíritu subversivo y utópico que anticipa un nuevo orden universal y que constituye una alternativa radical a la aristocracia mestiza del Inca Garcilaso y a las pretensiones de abolengo de Guaman Poma, los dos emblemas máximos de la cultura colonial del Perú ${ }^{76}$.

La lectura que tanto García Arenal como Adorno realizan enfatiza el hecho de que las falsificaciones obedecen a un deseo consciente de inventar un pasado allí donde las exigencias políticas del presente así lo demandan. En este sentido, la publicación de la Antiquitatum Variarum de Annio de Viterbo y su vasta difusión debe ser entendida en el contexto de la proyección de un modelo político e imperial cohesionado en torno a la institución monárquica, cuya legitimidad descansaba en la antigüedad y en la raigambre bíblica de sus orígenes. Dotando a la corona de Castilla y Aragón de un pasado común para sus recientes y heterogéneos dominios, Annio de Viterbo inauguró el desarrollo de una línea historiográfica oficial de corte nacionalista que tuvo como objetivo consolidar el poder de los Reyes Católicos frente a las demás monarquías europeas, modelo que fue reproducido durante el siglo XVI por cronistas vinculados directamente a la Corona como Nebrija, Ginés de Sepúlveda u Ocampo y por cosmógrafos oficiales como Chaves y Çamorano.

\footnotetext{
75 García Arenal y Barrios, 2008: 23.

76 Adorno, 11 (Argentina, 2000).
} 
Sarmiento de Gamboa, por su parte, al integrar las historias del falso Beroso y Xenofonte a la Historia de los Incas no hizo más que adscribir su crónica a esta corriente oficial de representación del pasado, tal como lo había hecho Fernández de Oviedo en su calidad de cronista de Carlos V. Esta identificación con una política de corte imperial fue coherente con el papel que la crónica jugó dentro del virreinato pues, en definitiva, al hacer que el fundador de la monarquía hispánica llegara al Nuevo Mundo antes que ningún otro rey, Sarmiento estaba demostrando la ilegitimidad del gobierno de los Incas en los Andes por otra vía, complementaria al testimonio de las panacas reales reunidas en la Prouança.

En la misma línea, la incorporación del relato de la Atlántida en el primer poblamiento de las Indias descrito en la Historia de los Incas también supuso la adscripción a un modelo nacionalista de representación del pasado en otro sentido, en la medida en que tal como ha señalado Pierre Vidal-Naquet, el mito de la Atlántida ha estado constantemente asociado a las corrientes nacionalistas europeas desde su divulgación durante el humanismo en adelante, incluyendo en esta categoría sobre todo a la España del siglo XVI y a la Alemania nazi. Las Atlántidas nacionales o el mito nacional-atlántico, como el autor ha denominado a este fenómeno, operó en el caso de ambas potencias recurriendo al pasado más lejano para que estas impusiesen sus pretensiones imperiales en el presente, proclamándose herederas de una patria imaginaria tan antigua como Atenas. Agustín de Zárate, López de Gómara y Sarmiento convirtieron a la Atlántida en el puente a través del cual el pasado del Nuevo Mundo se integró a las proyecciones imperiales del proyecto político de unificación de la cristiandad impulsado por los Reyes Católicos, más allá de la naturaleza fabulosa del relato. La fórmula Atlántidafalsario empleada por Sarmiento se repetiría en el futuro acomodándose a nuevos contextos y a la invención de nuevos pasados: en vísperas de la segunda guerra mundial Albert Herrmann, profesor de la Universidad de Berlín, publicó Nuestros Antepasados y la Atlántida, obra marcadamente nacionalista en la que el autor reconstituía las raíces del imperio germánico a partir del mito platónico y de la Chronique d'Ura-Linda, un texto espurio elaborado durante el siglo XIX. Herrmann, consciente de la falsedad de la crónica, pretendía demostrar que los pueblos germánicos habían conocido una edad de oro en el segundo milenio antes de la era cristiana y que la identificación de estos con los bárbaros era solo una consecuencia de la tardía introducción del cristianismo ${ }^{77}$.

77 Vidal-Naquet, 2006: 139. 
Más allá de la factura espuria de las invenciones de Annio de Viterbo o del componente fabuloso de la historia de la Atlántida hemos querido aquí dar cuenta de los motivos e intereses que subyacieron a la inclusión de estos relatos en la Historia de los Incas, ofreciendo una lectura que replanteara el rol que la historiografía positivista asignó a estas historias, al relegarlas a los dominios de la seudohistoria y excluirlas de un análisis que diera cuenta de los motivos e intereses que subyacían a su utilización. Al mismo tiempo, quisimos ofrecer una alternativa a los enfoques más contemporáneos que han orientado la discusión en torno a la dicotomía historia versus ficción, insistiendo en la idea de que las falsificaciones y las fábulas -independiente de si fueron verosímiles o no- responden a intereses que sí son reales y que deben ser entendidos en el contexto mismo de su producción.

\section{BiBLIOGRAFÍA}

Acosta, Joseph de, Historia Natural y moral de las Indias, México, FCE, 2006.

Adorno, Rolena, «La Pertinencia de los Estudios Coloniales para el nuevo Milenio», Andes: Revista de Antropología e Historia, Universidad de Salta, 11 (Argentina, 2000), disponible en: http://redalyc.uaemex.mx/redalyc/src/inicio/ArtPdfRed.jsp?i$\mathrm{Cve}=12701102$.

Annius, Johannes, Auctores Vetustissimi, vel Opera Diversorum Auctorum de Antiquitatibus Loquentium cum Commentario eiusdem Joh. Annii. Chronographia Etrusca et Italica. De Novem Institutionibus Etruscis. Quadraginta Quaestiones. De Primis Temporibus et Regibus Primis Hispaniae, Roma, Eucharius Silber, 1498.

Barros, José Miguel, Pedro Sarmiento de Gamboa: Avatares de un Caballero de Galicia, Santiago, Editorial Universitaria, 2006.

Benedeit, El viaje de san Brandán, Madrid, Siruela, 2002.

Bernal, Martín, Atenea negra, Barcelona, Editorial Crítica, 1993.

Borja Gómez, Jaime, Los indios Medievales de fray Pedro de Aguado, Bogotá, Centro Editorial Javeriano, 2002.

Brading, David, Orbe Indiano, México, Fondo de Cultura Económica, 1991.

Braude, Benjamin, «The sons of Noah and the Construction of ethnic and Geographical Identities in the Medieval and early modern Periods», The William and Mary Quarterly, 3d series/ LIV/ 1 (Virginia, 1997): 103-142.

Caballero López, José, «El «Beroso» de Annio de Viterbo y su Presencia en las Historias de España», Beroso. Revista de Investigación y Reflexión Histórica sobre la Antigüedad, 11-12 (La Rioja, 2004): 81-128. 
Cabello Valboa, Miguel, Miscelánea Antártica, Lima, Universidad Nacional Mayor de San Marcos, Instituto de Etnología, 1951.

Caro Baroja, Julio, Las falsificaciones de la Historia (en Relación con la de España), España, Editorial Seix Barral, 1992.

Castro Flores, Nelson, «Saber y Hegemonía en los Andes coloniales. La hipotiposis toledana. S. XVI», Manuscrito en elaboración, 2011.

Chaues, Hieronimo, Chronographia o Reportorio de los Tiempos, Sevilla, Impreso en casa de Fernando Díaz, 1584.

Çamorano, Rodrigo, Cronologia y Reportorio de la Razón de los Tiempos, Sevilla, Imprenta de Rodrigo de Cabrera, 1594.

Cieza de León, Pedro, Parte primera de la crónica del Perú, Venezuela, Fundación Biblioteca Ayacucho, 2005.

Cohn, Norman, Noah's flood. The Genesis story in Western thought, New Haven \& London, Yale University Press, 1999.

Córdoba, Pedro, «Las Leyendas en la Historiografía del Siglo de Oro: el caso de los "falsos Cronicones"», Revista Criticón, 30 (Toulouse, 1985): 235-253.

Durán, Diego, Historia de las Indias de Nueva-España y islas de tierra firme I, México, Imprenta de J. M. Andrade y F. Escalante, 1867.

Esdras IV, D. Muñoz León (ed.), Apócrifos del Antiguo Testamento VI, A. Díez Macho y Antonio Piñero (eds.), Madrid, Ediciones Cristiandad, 2009: 301-465.

Fernández de Córdova Millares, Álvaro, «Imagen de los reyes Católicos en la Roma Pontificia», Revista En la España Medieval, 28 (España, 2005): 259-354.

García-Arenal, Mercedes y Barrios, Manuel, «Los libros plúmbeos de Granada: nueva cita, nuevas Propuestas», Mercedes García-Arenal y Manuel Barrios (eds.), ¿La Historia Inventada? Los libros plúmbeos y el Legado Sacromontano, Granada, Universidad de Granada, Fundación El Legado Andalusí, 2008: 9-26.

García Hernán, Enrique, «La España de los Cronistas reales en los siglos XVI y XVII», Norba Revista de Historia, Universidad de Extremadura, 19 (Cáceres, 2006): 125-150.

Garcilasso de la Vega, Ynca, Historia General del Perv, Cordoua, Por la Viuda de Andres Barrera, 1617.

Grafton, Anthony, Falsarios y críticos. Creatividad e Impostura en la Tradición Occidental, Barcelona, Editorial Crítica, 2001.

Guaman Poma de Ayala, Felipe, Nueva Corónica y buen Gobierno, Copenhague, Edición virtual Det Kongelige Bibliotek, 2004.

Hampe, Teodoro, Cultura Barroca y Extirpación de Idolatrías. La Biblioteca de Francisco de Ávila-1648, Perú, Centro de Estudios Regionales Andinos Bartolomé de las Casas, 1996. 
Herrera y Tordesillas, Antonio de, Historia General de los hechos de los Castellanos en las islas i tierra firme del mar Oceano, 4 vols., Madrid, Imprenta Real de Nicolás Rodríguez, 1729.

Levillier, Roberto, Don Francisco de Toledo. Supremo Organizador del Perú (3v), Madrid, Espasa Calpe, S.A., 1935.

Lida de Malkiel, María Rosa, «Túbal, primer poblador de España», Revista Ábaco, 3 (Valencia, 1970): 9-48.

López de Gómara, Francisco, La Historia General de las Indias, y todo lo Acaecido en ellas dende que se Ganaron hasta agora y La Conquista de Mexico de la nueua España, Anuers, Mario Nucio, 1554.

Markham, Clements, Introduction to History of the Incas by Pedro Sarmiento de Gamboa and The Execution of the Inca Tupac Amaru by Baltasar de Ocampo, Cambridge, The Hakluyt Society, 1907.

Morales, Ernesto, Sarmiento de Gamboa: un Navegante Español del siglo XVI, Barcelona, Araluce, 1932.

O'Campo, Florián, Corónica General de España que Recopilaba el Maestro Florian de Ocampo, Madrid, Oficina de don Benito Cano, 1791.

O'Gorman, Edmundo, La Invención de América, México, Fondo de Cultura Económica, 2006.

Pease, Franklin, Las Crónicas y los Andes, Perú, Fondo de Cultura Económica, 1995.

Pietschmann, Richard, Introducción a Geschichte des Inkareiches von Pedro Sarmiento de Gamboa, Berlín, Weidmannsche Buchhandlung, 1906.

Porras Barrenechea, Raúl, Fuentes Históricas Peruanas (Apuntes de un curso Universitario), Lima, Instituto Raul Porras Barrenechea, Escuela de altos Estudios y de Investigaciones Peruanistas, Universidad Nacional Mayor de san Marcos, 1963.

Sánchez Alonso, Benito, Historia de la historiografía española (3v), Madrid, Publicaciones de la Revista de Filología Española, Consejo Superior de Investigaciones Científicas, 1947.

Sarmiento de Gamboa, Pedro, Historia de los Incas, Buenos Aires, EMECE, Imprenta López, 1942.

Steffen, Hans, «Anotaciones a la "Historia Indica" del Capitán Pedro Sarmiento de Gamboa», Anales de la Universidad de Chile, Imprenta Cervantes, CXXIX/ 69 (Santiago, 1912): 1107-1214.

Stephens, Walter, «When pope Noah ruled the Etruscans: Annius of Viterbo and his forged Antiquities», Modern Language notes, Italian issue Supplement: Studia Humanitatis: essays in honor of Salvatore Camporeale, 119/ 1 (Baltimore, 2004): 201-223. 
Tord, Luis Enrique, «Platón, la Atlántida y los cronistas del Perú», La Tradición Clásica en el Perú Virreinal, Perú, Fondo Editorial Universidad Nacional Mayor de san Marcos, 1999.

Veyne, Paul, ¿Creyeron los griegos en sus mitos?, España, Ediciones Granica, 1985.

Vidal-Naquet, Pierre, La Atlántida: Pequeña Historia de un mito Platónico, Madrid, Ediciones Akal, 2006.

White, Hayden, El texto Histórico como Artefacto Literario y otros Escritos, Ediciones Paidós Ibérica, 2003.

Wood, Christopher, «The Credulity Problem», Peter Miller and François Louis (ed.), In Press in Conference Proceedings, The age of the Antiquaries in Europe and China, 1400-1800, Bard Graduate Center, Yale University Press (Connecticut, 2006): 1-35.

Zárate, Agustín de, Historia del descubrimiento y conquista del Perú, Argentina, Publicaciones del Instituto de Historia Argentina y Americana, Universidad de Buenos Aires, 1965.

Fecha de recepción: 17 de marzo de 2010

Fecha de aceptación: 6 de febrero de 2012

\section{Geneaology of an origin: Tubal, the falsifier and Atlantis in the History of the Incas by Pedro Sarmiento de Gamboa}

The present article proposes a political reading of two texts that are connected to each other: the History of the Incas by Pedro Sarmiento de Gamboa and the Antiquitatum Variarum by Annio de Viterbo, a collection of spurious texts from the end of the $15^{\text {th }}$ century. Doing a synthesis between the Antiquitatum and the platonic myth of Atlantis, Sarmiento argued that the Indians were descendants of Túbal lineage, the grandson of Noah and founder of the Hispanic monarchy which had come to the Indies after the Universal Flood. It is proposed that the History of the Incas as well as the Antiquitatum were part of an official current of imperial representation of the past promoted by the Catholic Kings, that was projected to Spanish and Indies chronicles during the $16^{\text {th }}$ century.

Key words: Sarmiento de Gamboa; Annio de Viterbo; Túbal; Atlantis; settlement of the West Indies. 